\title{
Max Weber and the Empirical Historical Inquiry
}

Edith Hanke

\section{Abstract}

Max Weber is a worldwide respected sociologist, but there are other ways to approach and appreciate his oeuvre, especially in historical science. He has been seen as the last Germanspeaking polyhistor, as the founding father of historical cultural studies, and even as the forerunner of a problem-focused historiography. At the same time, history provides him with an almost inexhaustible reservoir of single data. Weber demonstrates what about data is scientifically interesting and how to make use of it for dealing with scientific questions. My approach in this essay will be as follows: Firstly, I will identify Weber's methodological reflections about how to deal with empirical-historical reality. Secondly, I will show how Weber embraces history with special focus on his sociology of domination - a centerpiece of Economy and Society. Finally, I will shortly explore the possibilities of adapting Weber's main theses to present-day historical sciences.

Keywords: Max Weber. Empirical historical knowledge. Science of reality. Sociology of domination.

\section{The question about empirical historical knowledge is at the same time a question about the relation between sociology and history}

Max Weber' was not a professional historian (HANKE, 2015). If one makes too narrow disciplinary boundaries the sole criterion for consideration, everything would be said with this sentence. Weber is a worldwide respected sociologist, but there are other ways to approach and appreciate his oeuvre, especially in historical science. Some see Weber as the

I This contribution was presented as a lecture at the "First International Meeting of the Young Weber Scholars Max-Weber-Network" in Hamburg, 29th November till Ist December 20 I7. It is a short version of the German publication: Max Weber und die historische Empirie (HANKE, 2015). Thanks to Sérgio da Mata and Arthur Alfaix Assis for the critical review of the text for the publication in Brazil.

$(\mathrm{cc}) \mathrm{Br}$
Direito autoral e licença de uso: Este artigo está licenciado sob uma Licença Creative Commons. Com essa licença você pode compartilhar, adaptar, para qualquer fim, desde que atribua a autoria da obra, forneça um link para a licença, e indicar se foram feitas alterações. 
last German-speaking polyhistor (MOMMSEN, 1986). ${ }^{2}$ To a generation of West-German historians he was the forerunner of social history and of a theory-driven historical science (KROLL, 2010). ${ }^{3}$ Throughout the Humanities, interdisciplinary-leaning scholars refer to him as the founding father of historical cultural studies (BRUCH; GRAF; HÜBINGER, 1989; HÜBINGER, [1889], 1997). ${ }^{4}$ Furthermore, for a group of historians aligned with French historiographical debates, Weber opened new research perspectives by providing a key to a problem-focused history (OXELE, 2011)..$^{5}$

Max Weber reveals an immense historical knowledge in his oeuvre, which can now be read in a complete historical-critical edition in 47 volumes, the Max-Weber-Gesamtausgabe (WEBER, [1984] 2020). ${ }^{6}$ Weber confidently surveys multiple periods and cultures, ranging from the music of the Weddah in Ceylon and the ancient Egyptian privileges of immunity, all the way to the treatises of the Quaker Robert Barclay. Experts and professional historians have accused Weber's research of dilettantism. Such criticism was already levelled during Weber's lifetime, and has been around ever since. It is usually related to the old and tiring dispute over disciplinary boundaries and hierarchies - whether a sociologist should be allowed to go poaching in the historians' territories, or the other way around, whether the historical science can be pushed aside into the role of sociology's maidservant.

Historical research provides the empirical material with which Max Weber operates. But sometimes Weber himself was engaged in inquiries about prevailing questions - "Enqueten" in the vocabulary of those days

2 On Max Weber's universal-historical approach, cf. Wolfgang J. Mommsen (1986, p. 5I-72) in Max Webers Begriff der Universalgeschichte.

3 On the so called Bielefeld School and the "Theory of History" research group, cf. Thomas Kroll (2010, p. 189205) in Die Max-Weber-Rezeption in der westdeutschen Historiographi.

4 Cf. Kultur und Kulturwissenschaften um 1900. Krise der Moderne und Glaube an die Wissenschaft (BRUCH; GRAF; HÜBINGER, [1889], 1997) and especially Max Weber und die historischen Kulturwissenschaften (HÜBINGER, 1988).

5 On the project of the former Max Planck Institute for History in Göttingen: Das Problem der Problemgeschichte (OXELE, 201I).

6 Max Weber-Gesamtausgabe (MWG), 47 vols. (WEBER, [1984] 2020). The critical edition presents Weber's work in three sections: Writings and Speeches (I), Letters (II), Lectures and Lecture Notes (III). 
-, e.g. concerning the agrarian question or the modern press. It is above all history, which provides him with an almost inexhaustible reservoir of single data regarding a nearly endless diversity of human action within social, economic, political, religious, and cultural realms. This means that history offers a mass of empirical data regarding human activities, which have been realized in whatever form or quality (KOSELLECK, 1988). ${ }^{7}$ We must notice that in Weber's time historical knowledge was available in archaeological findings, source books, and in the archives. The access was limited in space and time. Nowadays, global electronic networking has increased the availability of data, also for the academic access. We do have access to endless data at all times at almost all places of the world. Weber's works and his critical reflection show how an empirical science handles data. Weber demonstrates what about data is scientifically interesting and how to make use of data for dealing with scientific questions (Fragestellungen) (KOCKA, 1988).8

My approach will be as follows: Firstly, I will identify Weber's methodological reflections about how to deal with empirical-historical reality. Secondly, I will show how Weber embraces history with special focus on his Sociology of Domination - a centerpiece of Economy and Society. Finally, I will shortly explore the possibilities of adapting Weber's main theses to present-day historical sciences.

1. Max Weber's methodological reflections: About the "objectivity" of historical knowledge ${ }^{9}$

In the 1904 essay The 'objectivity' of knowledge in social science and social policy, which is supposed to furnish the program for the new journal Archiv für Sozialwissenschaft und Sozialpolitik, Weber develops his understanding of science, and outlines the basics of the "empirical social sciences of culture” (WEBER, [1900-1907], 2018b, p. 135-234, WEBER, 2012,

7 For more complex (and historical) definitions cf. in particular Reinhart Koselleck (1979, p. 593-595), introduction to the article Geschichte, Historie in which "history" is introduced as a concept of movement, action and legitimation.

8 As this article will also show, Weber's understanding of an empirical science is completely different from what is in our days referred to as "empirical social research".

9 As an example of the intensive work by historians about the subject, see: Jürgen Kocka (1988, p. 184-194) in Zwischen Elfenbeinturm und Praxisbezug. Max Weber und die "Objektivität" der Kulturwissenschaften. 
p. 137$).{ }^{10}$ In doing so, he also displays his own methodological program, which he keeps in force - with some modifications - up until his last piece of work (WEBER, [1919-1920] 2013a, [1908-1917], 2018f)." The Objectivity-essay is also a stance over the contemporary scientific debates: On the one hand, it touches the debate about the "crisis of historicism", in which Weber sets himself against historical-philosophical constructions such as Marxism and evolutionism, but also against positivism and naturalism (HÜBINGER, 1988, p. 270-271; HIDAS, 2014 , p. 22). ${ }^{12}$ On the other hand, Weber intervenes in a methodological debate that had been carried out by economists, establishing his own position between theory and empiricism (WEBER, [1900-1907], 2018a, p. $120-134,130) .^{13}$

a. The commitment to a "science of reality"

The Objectivity-essay can be read as a document, which defines economics as an empirical social science and as a historical cultural science (historische Kulturwissenschaft). Let us have a look at the often quoted and very much valuable statement:

The social science that we want to pursue is a science of reality. We want to understand the distinctive character of the reality of the life, in which we are placed and which surrounds us - on the one hand: "[...] the interrelation and the cultural significance and importance of its individual elements as they manifest themselves today; and on the other: the reasons why these elements historically developed as they did and not

10 Cf. Die "Objektivität" sozialwissenschaftlicher und sozialpolitischer Erkenntnis in Zur Logik und Methodik der Sozialwissenschaften. Schriften 1900-1907 (MWG I/7) (WEBER, [1900-1907], 2018a). English translation: Collected methodological writings (CMW) (WEBER, 2012).

II References in Soziologische Grundbegriffe in p. 146-215, here p. 156 and 172 (editor's notes 21 and 49) in MWG I/23 (WEBER, [1919-1920] 2013a, p. 146-215), but already in Der Sinn der “Wertfreiheit" der soziologischen und ökonomischen Wissenschaften in MWG I/I2 (WEBER, [1908-1917], 20I8f. p. 441-460).

12 Cf. Max Weber und die historischen Kulturwissenschaften; also cf. Zoltán Hidas in Entzauberte Geschichte. Max Weber und die Krise des Historismus (2004).

I3 Cf. also Edgar Jaffé, Werner Sombart and Max Weber, Geleitwort, in MWG I/7 (WEBER, [1900-1907], 20I8b); as well as the editor's note $2 \mathrm{I}$ concerning Werner Sombart's attempt to overcome the contrast between theory and empirical reality in: Werner Sombart (1902, p. X, XXIX, XXXII) in Der Moderne Kapitalismus. 
otherwise (So-und-nicht-anders-Gewordenseins)" (WEBER, [1900-1907], 2018b, p. 174, WEBER, 2012, p. 114). ${ }^{14}$

The fact that Weber places his focus on economics - "our discipline" (WEBER, [1900-1907], 2018b, p. 144, 2012, p. 101) - arises from his choice of subject, which he had taught since 1894. As early as in his lecture General (theoretical) political economy (Allgemeine (theoretische) Nationalökonomie) Weber wanted to put the economically acting "empirical human being" with its historical and individual needs in the center of his scientific interest (WEBER, [1894-1898], 2009a, p. 123, 205-206). ${ }^{15}$ For him, political economy was about historical knowledge and knowledge of the individual. In his essay Roscher and Knies and the logical problems of historical economics, the so-called "Seufzer"-Aufsatz (sigh-essay), Weber treats history as a "science of reality" (Wirklichkeitswissenschaft) (WEBER, [1900-1907], 2018c, p. 328-379, 338, 2012, p. 73). ${ }^{16}$ In his later article on the ancient historian Eduard Meyer, titled Critical studies in the logic of the cultural sciences, Weber puts an end to the popular and simplifying prejudice about history “[...] as being 'purely' the description of given realities, or the simple reproduction of 'facts"' (WEBER, [1900-1907], 2018c, p. 380-480, 413, 2012, p. 152). ${ }^{17}$ The aim of a historical reflection - positively turned and as Weber has put it in the Objectivity-essay - is the "knowledge of relationships that are significant from individual points of view" (WEBER, [1900-1907], 2018b, p. 226, 2012, p. 135). ${ }^{18}$ Thus, Weber puts historical and social-scientific knowledge closely together within a "science of reality", while distinguishing this - as also did Heinrich Rickert (1986, p. 369) - from the "science of nature" and jurisprudence. ${ }^{19}$ However,

14 Cf. MWG I/7; CMW.

15 Cf. Allgemeine ("theoretische") Nationalökonomie. Vorlesungen 1894-I898 in MWG III/I (WEBER, [18941898], 2009a, p. 123, 205-206). In a last posthumously published essay that summarizes the results of the knowledge gained from the editing process, Wolfgang J. Mommsen has built a methodological bridge between this lecture and the Objectivity essay from 1904, cf. Mommsen (2004, p. 3-35) in Max Weber als Nationalökonom. Von der Theoretischen Nationalökonomie zur Kulturwissenschaft.

16 Weber, Roscher und Knies und die logischen Probleme der historischen Nationalökonomie. (Dritter Artikel). II. Knies und das Irrationalitätsproblem (Fortsetzung), cf. MWG I/7 and CMW.

17 Cf. Kritische Studien auf dem Gebiet der kulturwissenschaftlichen Logik (WEBER, [1900-1907], 2018c).

18 Cf. MWG $1 / 7$ and CMW.

19 See Heinrich Rickert (1986) in Die Grenzen der naturwissenschaftlichen Begriffsbildung. Eine logische Einleitung in die historischen Wissenschaften. For Rickert a historical science is a "...] science of reality, insofar as it has 
Weber would later distance himself from Rickert's concept of "science of reality", and would solely resort to terms such as "empirical science" or “'empirical' discipline” (WEBER, [1900-1907], 2018b, 2012). ${ }^{20}$

a. Empirical historical knowledge

How is historical knowledge generally possible? Referring to Kant's knowledge theory Weber states:

"What we seek knowledge of is a historical phenomenon, that is, one that is significant in its distinctive character. And the crucial point in this connection is the following: the idea of acquiring knowledge of individual phenomena does not make logical sense at all unless one presupposes that only a finite part of the infinite multitude of phenomena is significant" (WEBER, [1900-1907], 2018b, p. 184, 2012, p. 117).

An "objective knowledge" of the historical (empirical) reality is hence closely tied to the transcendental precondition - as defined by Kant - that there is a recognizing subject with the capability to take a position to its world's surroundings. Thus, "objectivity" is closely tied to a radically subjective precondition - and this is the reason why Weber puts objectivity in quotation marks in the title of his essay. In contrast to Kant, Weber does not proclaim the cognizing subject's faculty to reason as the determining precondition for knowledge, but rather the fact "[...] that we are cultural beings, endowed with the capacity and the will to adopt a deliberate position with the respect to the world, and to bestow meaning upon it" (WEBER, [1900-1907], 2018b, p. 188-189, 2012, p. 119): This is when the historical cultural sciences came into being (HÜBINGER,

to do with unique and individual realities as such. It is science of reality, insofar as it takes a widely accepted observation standpoint, and therefore takes as subject of representation only the individual realities that are meaningful by reference to a general value, or the historical singularities" (RICKERT, 1896, p. 369). Cf. Weber ([1900-1907], 2018b, p. 174), editor's note 97, and Rickert and Grenzen, p. 257, 263, 30I, 369, 480, who distinguishes between conceptual sciences and sciences of reality, although he designates the conceptual sciences as natural sciences or sciences of laws, and the sciences of reality as historical sciences - cf. Weber (1900-1907], 2018a, p. 45) Roscher und Knies I, MWG I/7, editor's note 25). Weber separates "empirical" from "dogmatic" knowledge. Cf. Weber, R. Stammler's "Überwindung" der materialistischen Geschichtsauffassung, in MWG I/7 (WEBER, [1900-1907], 2018c, p. 48I-57I, 529); CMW (WEBER, 2012, p. 203): "dogmatic disciplines" vs. "those disciplines whose aim is [to furnish] an empirical-causal 'explanation".

20 For instance Stammler in MWG I/7 (WEBER, [1900-1907], 2018c, p. 522, 509) and "empirical discipline such as social science in our sense of the word" in CMW (WEBER, 2012, p. 194, 201). 
1988, 2000). ${ }^{21}$ According to Weber, the existence of "culture" as a place of voluntarist assignment of meaning is a general condition beyond science, which, however, enables historical and social-scientific knowledge.

In addition, Weber even goes another step further. He deduces from that position the radical perspectivity of knowledge - the idea that knowledge is always "knowledge from specific and particular points of view" (die Erkenntnis unter spezifisch besonderten Gesichtspunkten). ${ }^{22}$ And, he proclaims this perspectivity to be the fundamental precondition for the empirical cultural sciences (HÜBINGER, 2012). ${ }^{23}$ The historian and social researcher has to bring the capability to judge when selecting data. He has to be capable of distinguishing the relevant from the irrelevant in order to choose the fractional amount of empirical data, which he considers to be relevant for his approach. He can only do so with reference to the value ideas, which affect him as well as the prevailing collective mindset. Weber points out subsequently that he owes the idea of "value-relation" (Wertbeziehung) to his friend and philosopher Heinrich Rickert. Within the Objectivity-essay Weber composes the image of a researcher who has to be very conscious of his own mindset and set of values, so that he can distance himself from it when examining the mere facts. It is the combination of the well-considered handling of oneself, the object of research, and the cultural framework conditions that underlies the high intellectual standard that Weber wants to base every work in the humanities. For this standard, he established the formula of "intellectual honesty" (WEBER, [1917-1919], 1992, p. 49-111, 97, 2012, p. 346). ${ }^{24}$ Weber's claim continues today as a source of fascination for intellectual history.

21 Gangolf Hübinger (1988, p. 269-282) in Max Weber und die historischen Kulturwissenschaften; cf. also Hübinger (2000, 162-177) in Die "Rückkehr" der Kulturgeschichte.

22 Cf. MWG I/7; CMW (WEBER, [1900-1907], 2018b, p. 189, 2012, p. 119) and later: "It is true that arranging facts [so that they constitute] a concrete interconnection, and [establishing] 'law-like regularities' by means of abstraction from facts, are both processes that are usually governed by their own separate 'viewpoint' (indeed, the division of labour among the various specialized disciplines rests on this foundation). But, for precisely that reason, it surely seems impossible to speak of one 'unconditional' point of view [governing] all empirical disciplines" - Stammler in MWG I/7; CMW (WEBER, [1900-1907], 2018a, p. 504-505, 2012, p. 192).

23 For Hübinger, Weber is "a radikal perspectivist", cf. Hübinger (2012, p. 42) in Über die Aufgaben des Historikers.

24 Cf. Wissenschaft als Beruf in MWG I/I7; CMW 


\section{a. Methodological instruments}

Weber's methodological approach derives from the aforementioned knowledge-preconditions. Weber builds a bridge between the generalizing and the individualizing ways of knowledge, aided by the juridical "methods of causal imputation” (Methoden kausaler Zurechnung) (WEBER, [19081917], 2018d, p. 383-440, 391, [1900-1907], 2018b, p. 185, 2012, p. 274). ${ }^{25}$ This is not about a reproduction of the entire reality, something that would be simply impossible und scientifically nonsensical. On the contrary, it is about a rational and causal choice of criteria that are relevant for an action or an event, as they have led to a specific outcome in history - thus making it explicable.

We only pick out those causes to which the 'important' elements of a sequence of events can, in each individual case, be imputed. Where the individuality of a phenomenon is concerned, the question of causes is not a question of laws but of concrete causal relationships; not a question of the formula under which the phenomenon can be subsumed as a specimen, but a question of the individual constellation to which it should imputed as a result: it is a question of imputation. (WEBER, [1900-1907], 2018b, p. 185, 2012, p. 118).

Weber emphasizes that "[...] the causal imputation is carried out in the form of an intellectual process that comprises a number of abstractions" (WEBER, [1900-1907], 2018c, p. 457, 2012, p. 173-174). So that it only a little step toward the elaboration of "ideal types" (WEBER, [19081917] 2018e, p. 329-382, 379). ${ }^{26}$ They are "mental images", which "[...] bring together certain relationships and events of historical life to form an internally consistent cosmos of imagined interrelations" (WEBER, [1900-1907], 2018a, p. 202, 2012, p. 124). They are by no means hypotheses, but at best, a step towards formulating a hypothesis (WEBER, [1900-1907], 2018b, p. 203). ${ }^{27}$ Through ideal-types and the judgment of ascription, we are able to measure "certain significant components"

25 Cf. Über einige Kategorien der verstehenden Soziologie in MWG I/I2 (WEBER, [1908-1917], 2018d); Cf. MWG I/7 and CMW; with the editor's note 39 referring to Gustav Radbruch (1902, p. 2) in Die Lehre von der adäquaten Verursachung.

26 Cf. Beitrag zur Werturteildiskussion im Ausschußdes Vereins für Sozialpolitik in MWG I/I2 (WEBER, [19081917] 2018e).

27 Cf. MWG I/7; CMW: "it is not a 'hypothesis', but it seeks to guide the formulation of hypotheses" (WEBER, 2012, p. 125). 
of the historical reality in its empirical shape (LEPSIUS, 2003, p. 32-41), ${ }^{28}$ or to explain historical events by their "real causes" (WEBER, [19001907], 2018a, p. 220, 2012, 132). In The Protestant Ethic and the 'Spirit' of Capitalism, written by Weber at the same time he was working on the Objectivity-essay, he demonstrates how complex the ideal construct can be, especially via the "spirit' of capitalism" (WEBER, [1904-1911] 2014, p. 12-22). ${ }^{29}$ In connection with the defense of his "cultural historical essay" (SCHLUCHTER, 2005, p. 49-73), ${ }^{30}$ he also uses the term "historische Empirie", which could be translated as "empirical historical inquiry". ${ }^{31}$ This translation seems to meet the contextual meaning of the Protestant Ethic Debate, but to me the German term is different, because it does not include the "inquiry" or method.

Thus the construction of concepts and ideal types itself, assuming that they are not to be frozen into a dogmatic system, underlies "the discursive character of our cognition” (WEBER, [1900-1907], 2018b, p. 208, 2012, p. 127). ${ }^{32}$ Weber says, "that we only grasp reality through a sequence of ideational changes" (eine Kette von Vorstellungsveränderungen) (WEBER, [1900-1907], 2018b, p. 208, 2012, p. 127). Hence, Weber states, that "some sciences are fated to remain eternally youthful, namely all historical disciplines (WEBER, [1900-1907], 2018b, p. 224, 2012, p. 133). This

28 Cf. MWG I/7; CMW: On the meaning of imputation cf. M. Rainer Lepsius (1990, p. 31-43) in Interessen und Ideen and Lepsius (2003) in Eigenart und Potenzial des Weber-Paradigmas.

29 Wolfgang Schluchter points out this parallelism in his introduction to the edition of Weber's "Protestantische Ethik", in Max Weber ([1904-191 I] 2014, p. 12-22) in Asketischer Protestantismus und Kapitalismus. Schriften und Reden 1904-191/: "2. Logisch-methodische Selbstvergewisserung: Die Objektivität sozialwisse schaftlicher und sozialpolitischer Erkenntnis"; cf. Die protestantische Ethik und der Geist Des Kapitalismus in MWG I/9 (WEBER, [1904-19II] 20I4, p. I4I-142, 214, 246-247), "as well as in both replies to Rachfahl" in MWG I/9 - p. 515-619, and p. 620-740, each with explicit references to the Objectivity-essay (p. 613, footnote 31 with editor's note 17, and p. 709 with editor's note 76).

30 Weber's words in his letter to Heinrich Rickert on april 2, 1905. Cf. Briefe 1903-1905 in MWG II/4 (WEBER, [1903-1905] 2015, p. 445-448): culturgeschichtlicher Aufsatz, with the beautiful remark that his article was "a kind of 'spiritualistic' construction of the modern economy". Cf. Wolfgang Schluchter (2005): Wie Ideen in der Geschichte wirke': Exemplarisches in der Studie über den asketischen Protestantismus.

31 These words are quite hidden in a footnote, as the opposite of Benjamin Franklin's Advice to a young tradesman, cf. The Protestant Ethic Debate. Max Weber's Replies to his Critics 1907-1910 (CHALCRAFT; HARRINGTON, 200I, p. 38). "The 'explanatory theories' my critic invokes in these two distinguished scholars are specifically English in character, and in part themselves late expressions of that 'natural' outlook on life that we also find in Franklin. Yet they represent the very reverse of empirical historical inquiry". 
implies an immense dynamic, which is dependent on the change of culture at least, and which is then continuously required to forge new instruments of cognition (WEBER, [1900-1907], 2018b, p. 225, 2012, p. 134).

\section{The feasibility of the approach - the Sociology of Domination as a test case}

Weber's Sociology of Domination is a long-time project, which lasts from 1909 up until 1920. He worked on it interruptedly up to his death. This study is one of his texts, which in an impressive way concentrates at a small space a vast amount of historical data, comparisons and examples. In fact, with a competent crossing of the boundaries of epochs and cultures, it is a marvelous universal-historical didactic piece. Béatrice Hibou (2014) enthusiastically describes the fascination of such an empirical-historical diversity and knowledge in her discussion of the French translation of the older version of Sociology of Domination. ${ }^{33}$ Hibou herself utilizes the domination categories for an empirical research of the former French colonies in North Africa.

Weber's handling of history is dependent on the conceptual structure of Economy and Society, in which he embeds the Sociology of Domination and which changes up until the latest version of 1920 . The older version is conceptually influenced by the essay On some categories of interpretive sociology from 1913, but also in large parts by the Objectivity-essay from 1904. Thus it must be read as a part of a cultural historiography, which depicts "the reasons why these elements historically developed as they did and not otherwise" (WEBER, [1900-1907], 2018b, p. 196, 2012, p. 114).$^{34}$ Since 1911 , it is also oriented towards the rationality theorem (WEBER, 2009, p. 163-167). ${ }^{35}$ In the latest version, Weber operates with the Basic Sociological Concepts prior to classifying historical examples by categories.

33 Cf. Béatrice Hibou (2014, p. 2-21) in De l'intérêt de lire La Domination de Max Weber aujourd'hui.

34 Cf. MWG I/7; CMW

35 Cf. Introduction to Grundriß der Sozialökonomik from june 2, 1914: "It was assumed that the economic development should be understood primarily as a distinct and partial phenomenon of the general rationalization of life" - cf. Wirtschaft und Gesellschaft. Entstehungsgeschichte und Dokumente in MWG I/24 (WEBER, 2009, p. 163-167). 
a. Structural forms and the conceptualization of types

Weber struggled much to find a suitable representational format for his complex project Economy and Society, or, as he puts it in 1914, Economy and the social orders and powers (Die Wirtschaft und die gesellschaftlichen Ordnungen und Mächte) (WEBER, [1922] 2013c, p. XI). ${ }^{36}$ Weber once mentioned to the pianist Mina Tobler that he would have preferred to use a writing technique allowing him - as with scores - to say many things separated side by side and still at the same time. ${ }^{37}$ Especially with Sociology of Domination there was a high risk to fall back into familiar forms of historical narratives focusing on powerful states and grand personalities.

Weber, on the contrary, writes his history of rulership without resorting to these old narratives, rather laying his focus on structures, more precisely on the structural forms. He develops superordinate concepts, which circumscribe certain structural forms of authority: bureaucracy (Bürokratismus), ${ }^{38}$ patrimonialism, feudalism, and charismatic authority (Charismatismus) (WEBER, [1922] 2013c, p. 219)..$^{39}$ This listing documents a huge degree of concept-formation. Although Weber was able to refer to approaches developed by other authors, he was the one who coined this very specific conceptual framework. In doing so, he acts on the assumption that bureaucracy is the most rational form of domination, and by comparison, he accentuates the characteristics of the other and older forms of domination (WEBER, [1913-1914] 2003d, p. 724). ${ }^{40}$ Hence, he has a comparative approach. On an abstract level, this method is exactly as described in the Objectivity-essay.

36 Cf. Economy and Society.

37 This statement was registered by Eduard Baumgarten (1964, p. 482-483) in Max Weber. Werk und Person. It was said in connection with the first concert tour the Webers and Mina Tobler made together to Bayreuth and Munich in the summer of 1912. It seems to me that Weber considered the narrative question, which is so important for historians, as a secondary one.

38 Cf. Economy and Society: "bureaucracy" or "bureaucratic structure" (WEBER, [1922] 2013c, p. 964). The German term "Bürokratismus" - i.e. MWG I/22-4 (WEBER, [1919-1920] 2005, p. 169) means even more than only bureaucracy; it implies the system of bureaucracy.

39 Cf. Economy and Society: "charismatic components" (WEBER, [1922] 2013c, p. 219); this is only a weak translation of "Charismatismus" - cf. MWG I/23 (WEBER, [1919-1920] 2013, p. 459).

40 Weber writes to Georg von Below on this subject on June 2I, 1914 that he discussed "the form of political associations in a comparative and systematic way" in Economy and Society. Cf. Briefe 19/3-19/4 MWG II/8. 
Structural forms furthermore allow for a comparison with other structural forms. This means that Weber can compare bureaucratic structural forms with capitalistic structural forms, or feudal structural forms with forms of the profit-making enterprises and so forth (WEBER, [1919-1920] 2005, p. 418-453). ${ }^{41}$ At the same time, Weber can find capitalistic types of business also in ancient times, not only in the modern age. After beginning with structural forms, Weber moves on to the conceptualization of types, to arrive at the famous "three pure types of legitimate domination". These allow for comparison of empirical-historical phenomena, regardless of which epoch or culture, and, for example, for testing them for their bureaucratic or patrimonial kernel. Referring to the relation of types of domination and empirical-historical inquiry, Weber states: "[...] the 'pure' types of domination correspond to these three possible types of legitimation. The forms of domination occurring in historical reality constitute combinations, mixtures, adaptions, or modifications of those 'pure' types" (WEBER, [1919-1920] 2005, p. 148, [1922] 2013c, p. 964). ${ }^{42}$

a. The historical variety

The older version of Sociology of Domination reads, despite its structural approach, mostly like a history of events - though at a high universalhistorical level. Descriptive passages take turns with systematic elaborations in note form; in between, we find consistent episodes through the entire world history, often also in a short, staccato-like sequence. Weber displays an immense historical insight and uses it systematically. However, he also decodes - in a way that is also distinguishable in his writing Economic Ethics of the World Religions (Wirtschaftsethik der Weltreligionen) - entirely new domains, which are unfamiliar to him, especially from the Asian world. Thus, for explaining the non-monetary commodity-coverage, he

$4 \mathrm{I} \mathrm{Cf.} \mathrm{in} \mathrm{particular} \mathrm{the} \mathrm{section} \mathrm{Patrimoniale} \mathrm{und} \mathrm{feudale} \mathrm{Strukturformen} \mathrm{der} \mathrm{Herrschaft} \mathrm{in} \mathrm{ihrem} \mathrm{Verhältnis} \mathrm{zur}$ Wirtschaft in Wirtschaft und Gesellschaft. Nachlass. Teilband: Herrschaft in MWG 1/22-4 (WEBER, [19191920] 2005, p. 169). Weber criticizes the Marxist statement: "the hand-mill requires feudalism as the steam-mill necessitates capitalism" - p. 419 with editor's note 2; cf. Economy and Society (WEBER, [1922] 20I3c, p. 109 I). In his Poverty of Philosophy, Marx writes: "The hand-mill gives you society with the feudal lords; the steam-mill society with the industrial capitalists" in Das Elend der Philosophie (MARX, 1972, p. 130).

42 Herrschaft (MWG I/22-4); Economy and Society. 
engages himself in, for example, Egyptian "magazine administration" (WEBER, [1919-1920] 2005, p. 319, [1922] 2013c, p. 1043), "43 "Islamic warrior's fief" (WEBER, [1919-1920] 2005, p. 392, [1922] 2013c, p. 1076 $)^{44}$ or the Chinese tax-system. Weber was very well aware of falling for the "anathema" of dilettantism, as he wrote to the historian Georg von Below in June 1914 (WEBER, [1913-1914] 2003d, p. 724).45 The accusations last to this day, rendering that Weber had had too little expertise of Chinese, Islamic and so forth history. By the editorial revision of his work and its contextualization in the Max Weber-Gesamtausgabe, we can meet the following statements: 1) Weber can rely on an enormous stock of knowledge (saturated by his knowledge of sources and secondary literature), which he establishes before his illness and which is just recently in evidence by the edition of the early lectures; 2) Weber refers to the sources and research works that are linguistically accessible to him - for example in the case of the Chinese history he uses the works of missionaries and the "Peking Gazette", an English edition of internal government directives, which was only available in Berlin libraries (WEBER, [19151920], 1989, p. 132);46 3) Weber's approach is very selective - as proven by his handwritten notes in the books used by him. Hence, the question about what he could know is rather subordinated to the question, about what did he want to know.

Weber's handling of the history is best illustrated in a passage from the older version of Sociology of Domination:

"Historical examples of relatively clearly developed and quantitatively large bureaucracies are: (a) Egypt, during the period of the New Kingdom, although with strong patrimonial elements; (b) the later Roman Principate, and especially the Diocletian monarchy and the Byzantine polity which developed out of it; these, too, contained strong feudal and patrimonial

\footnotetext{
43 Patrimonialismus (MWG I/22-4); Economy and Society.

44 Feudalismus (MWG I/22-4); Economy and Society.

45 Letter to Georg von Below from June 21, 1914 in MWG II/8.

46 Cf. Edith Hanke Einleitung in MWG I/22-4 (WEBER, [1919-1920] 2005, p. I-9I, 59-60). In his "Confucianism" study, Max Weber used the "Peking Gazette" (which still today can only be borrowed from the Berlin State Library) several times to portray the Imperial Period during the last third of the 19th century. Cf. Wirtschaftsethik der Weltreligionen. Konfuzianismus und Taoismus. Schriften 1915-1920 (MWG I/19).
} 
admixtures; (c) The Roman Catholic Church, increasingly so since the end of the thirteenth century; (d) China, from the time of Shi Hwangti until the present, but with strong patrimonial and prebendal elements; (e) in ever purer forms, the modern European states, and, increasingly, all public bodies since the time of princely absolutism; (f) the large modern capitalist enterprise, proportional to its size and complexity" (WEBER, [1919-1920] 2005, p. 169-170, [1922] 2013). ${ }^{47}$

This breathtaking list demonstrates how Weber tries to determine the characteristics of bureaucratic administration both, systematically and in their historical shading. It is history providing him the data to do so. Furthermore, this shows that the occidental specificities touch most strongly the rationally designed ideal-type. Weber's former empirical historical interest shifts - parallel to the conceptualization of sociology - to a type-focused empirical interest. In December 1913 he writes to Hermann Kantorowicz: "It is an attempt to understand the 'sociological political science' as a science of the mere empirical typical human action" (WEBER, [1913-1914] 2003d, p. 442). ${ }^{48}$

Weber takes another step further in the new version of Sociology of Domination in 1920. He still refers to historical examples, but even if considered merely typographically, compared to the categories they slide in the fine print. Now Weber prefers quite clearly the conceptual classification. Nevertheless, the reference to historical reality remains important to him. It is not canceled. It argues for Weber's historical sensitivity, when he expresses the fear that the endless variety of history could be oppressed by conceptualization (WEBER, [1915-1920], 1989, p. 126). ${ }^{49}$

\section{a. Concept and conceptual content}

With the first draft of Economy and Society Weber lays the conceptual foundation of his sociology. The new Sociology of Domination presents

47 Bürokratismus (MWG I/22-4) and Economy and Society.

48 Max Weber's letter to Hermann Kantorowicz from December 29, 1913, MWG II/8: "It is an attempt to [...] understand the "sociological state theory" as a doctrine of purely empirical, typical human action". Emphasis are mine (WEBER, [1913-1914] 2003, p. 442).

49 Einleitung, in MWG I/19. This quote can be found in the shorter version of the types of domination in MWG I/I9 (WEBER, [1915-1920], 1989, p. 119-126) with very good comments on the relationship between reality and the concept of domination. 
itself as a strong typology of rulership. It seems like Weber casts a narrow net of concepts and afterwards gets himself mousetrapped in a generalized science, in which reality is deduced from a narrow system of concepts. Weber does not want this to happen, because he still sets off his kind of conceptualization against that of an abstract theory. He emphasizes that: "[...] in reality, action takes exactly this course only in unusual cases; and even then there is usually only an approximation to the ideal type" (WEBER, [1919-1920] 2013a, p. 156, [1922] 2013a, p. 9). ${ }^{50}$ In terms of the types of domination, he also accentuates "the fact that none of these three ideal types is usually to be found in historical cases in 'pure' form" (WEBER, [1919-1920] 2013b, p. 45, 2012, p. 216). ${ }^{51}$ However, Weber now separates precisely - by distinct self-reflection of his standpoint - the difference between historical and sociological research:

"We have taken for granted that sociology seeks to formulate type concepts and generalized uniformities of empirical process. This distinguishes it from history, which is oriented to the causal analysis and explanation of individual actions, structures, and personalities possessing cultural significance"; he furthermore continues: "As in the case of every generalizing science the abstract character of the concepts of sociology is responsible for the fact that, compared with actual historical reality, they are relatively lacking in fullness of concrete content" (WEBER, [19191920] 2013a, p. 169-170, 2012, p. 19-20). ${ }^{52}$

With reference to the analysis of domination, sociology can render a service to the historical work: "[...] it can in the particular case of a concrete form of authority determine, what conforms to, or approximates such types as, 'Charisma', 'patriarchy', 'bureaucracy', the authority of status groups, and in doing so, it can. work with relatively unambiguous

50 Cf. Soziologische Grundbegriffe in MWG I/23; Economy and Society (WEBER, [1922] 2013a, p. 9) - with reference to the Objectivity-essay.

51 Cf. Die Typen der Herrschaft in MWG I/23 (WEBER, [1919-1920] 2013b); Economy and Society.

52 Cf. Soziologische Grundbegriffe in MWG I/23 (WEBER, [1919-1920] 2013a); Economy and Society. Regarding this passage, see also: Schluchter (2003, p. 42-74, 53) in Handlung, Ordnung und Kultur. Grundzüge eines weberianischen Forschungsprogramms; as well as the constructive mediation attempt by Mario Rainer Lepsius (1982, p. I 18-138) in Zum Verhältnis von Geschichtswissenschaft und Soziologie. 
concepts" (WEBER, [1919-1920] 2013a, [1922] 2013c, p. 216). ${ }^{53}$ After all, this is still a great advantage.

For Weber, the quality of concept formation is always measured by the extent to which it serves the cognition of reality. Despite the strict conceptual classification in the latest version of Economy and Society, including The types of legitimate Domination, Weber undertakes modifications that are due to the radical changes within the German society, caused by World War I and the revolution of 1918/19. Weber records the dynamics and tries to meet them analytically with new conceptual proposals. This is within the new Sociology of Domination: "traditionalistische Revolution" and "charismatische Führer-revolutionen" (traditionalist revolution and revolutions under a charismatic leader) (WEBER, [1919-1920] 2013b, p. 469-470, 508, [1922] 2013c, p. 227-252), ${ }^{54}$ or by the terminological diversification of the party- and colleagueship-concept as well as the different forms of representation. We can discover approaches of a theory of democracy behind it (HÜBINGER, 2011). ${ }^{55}$ By the way, in 1917 Weber had thought about adding a forth type to the three types of domination; this was the one of democratic legitimation (WEBER, [1919-1920] 2005, p. 745-759). ${ }^{56}$

Weber also separates himself more and more from everyday language in order to stress the special access of sciences. Especially in the economic chapter, for a theory of money, he introduces subsequent to Georg Friedrich Knapp a relatively hyped-up artificial language. ${ }^{57}$ At the same time, it is a stroke against

53 Cf. Die Typen der Herrschaft in MWG I/23; Economy and Society.

54 Cf. Die Typen der Herrschaft in MWG I/23; Economy and Society. For the background, see Edith Hanke (2013, p. 11-32) in Rivoluzione e carisma. Concetti del cambiamento nel pensiero di Max Weber.

55 Hübinger sees a "historical theory of democracy" and a "historical political theory" in Weber. Cf. Hübinger (2005, p. 75-86), Max Webers Geschichtsdenken. See also Hübinger (201 Ia, p. 443-452) in Die "Staatssoziologie" Max Webers. Weber's last lecture in Munich on Allgemeine Staatslehre und Politik (Staatssoziologie). Unvollendet. Mit- und Nachschriften 1920, MWG III/7: "in the summer term 1920 is a parallel piece to the chapter "The types of domination" in the new version of Economy and Society 1919/20, but also with some significant discrepancies, that Hübinger points out in his "Introduction" to Weber ([1920], 2009b. p. 33-39).

56 Probleme der Staatssoziologie. Lecture in Vienna, october 25, 1917 in MWG I/22-4 (WEBER, [1 9 I 9- 1920] 2005, p. 745-759).

57 In particular, Knut Borchardt pointed this out orally during the editing work on MWG I/23 (WEBER, [19191920] 2013). 
combat-terms of his time, and thus, he does not talk about "capitalism" and "socialism", but about "market economics" and "planned economics" ${ }^{88}$ This creates analytical distance and an objectification of the debate. Still unnoticed in many cases remain the new conceptual creations and new connotations, such as "Appropriation" (actual control) or "Verfügungsgewalt" (power of control and disposal) (WEBER, [1919-1920] 2013, p. 172, [1922] 2013c, p. 22), ${ }^{59}$ whose analytical potential is still to be tested.

\section{The up-to-dateness of the approach - A "turn" backward}

How can historical science deal with Weber nowadays? How can it benefit from him? Gangolf Hübinger, editor of the Max WeberGesamtausgabe und historian, advocates a reconsideration of Weber's historical thinking in the face of "[...] the ramification of the historical reasoning, due to 'turns' becoming more and more fragmented, in more and more rapid changes" (HÜBINGER, 2005, p. 79, 2012, p. 53). ${ }^{60}$ In doing so, he puts emphasis on Weber's perspective and particular viewpoints: "The fields of inquiry of scientific disciplines are based not on 'concrete' relations between 'things', but on 'theoretical' relations between 'problems'" (WEBER, [1900-1907], 2018b, p. 167-168, 2012, p. 111).61

This way of doing historical science implies the profound coping scholar who is very aware of his own point of view. Especially in the cultural sciences, that are on Weber's side and thereby are bound to the conditions of the classic modernity, it is inevitable to critically question the present

58 Conf. Soziologische Grundkategorien des Wirtschaftens in MWG 1/23, esp. § 14. Verkehrswirtschaft und Planwirtschaft (WEBER, [1919-1920] 2013, p. 288-295, 288); translation: Economy and Society (WEBER, [1922] 2013c, p. 109).

59 Weber, Soziologische Grundkategorien des Wirtschaftens, in MWG I/23 (WEBER, [1919-1920] 2013, p. 172); Economy and Society (WEBER, [1922] 2013c, p. 22). See the register entries to MWG I/23, as well as Hübinger's remark on "appropriation" as an useful "category for type-building of social orders and explaining social change in different civilizations and epochs" in Weber's "sociology of law, economy, religion and domination" (HÜBINGER, 201 la, p. 445).

60 Hübinger (2005, p. 79) in Max Webers Geschichtsdenken and Hübinger (2012, p. 53) in Über die Aufgaben des Historikers.

6 Cf. MWG I/7; CMW. 
cultural conditions and to specify the point of view (HÜBINGER, 2011, p. 86). ${ }^{62}$ Where are the problems located today? How did the cultural frameworks shift due to globalization and the new media? Which stock of concepts can still be used today? Where do we need new concepts and analytical frameworks, especially concerning the new empirical basis in the “digital humanities"? (HABERKORN, 2014) ${ }^{63}$

Weber's sociology flows - as Rainer Lepsius (2003, p. 33), a famous German sociologist and coordinating editor of the Max WeberGesamtausgabe until his death in 2014, once put it - in the three-pole space of sequences of action, generation of structure, and projection of meaning. ${ }^{64}$ Thus, it also aims at an understanding of history, which is geared to a meaning-related human action. In addition, we have to acknowledge that a historical science, which is Weber-oriented is theory- and conceptattended. The Weberian concept formation is - again in the words of Lepsius (2003, p. 35) - not a taxonomy of facts, but an identification of analytical dimensions. Lepsius (1993a, 1993b) himself has demonstrated with his essays about the social-moral milieu and Hitler's charisma ${ }^{65}$ the analytical potential of a historical science as defined by Max Weber. Sociologists are searching for possibilities of application. In doing so, the "Weberparadigm" stands for a particular, autonomous type of theory. ${ }^{66}$ Historians could learn from that, but without denying their specific knowledge and their intellectual potential, because their task implies, as Weber states it very clearly, "[...] the causal analysis and explanation of individual actions,

62 In connection with the "preliminary remark" to the Gesammelte Aufsätze zur Religionssoziologie, Hübinger sees in Weber's approach a research program in "universal-historical problems" that remains attractive today. Cf. Kapitalismus, Religion und Herrschaft (HÜBINGER, 2006. p. 132-160) and Universalgeschichtliche Probleme im Anschluß an Max Weber (HÜBINGER, 2002, p. 97-99).

63 Tobias Haberkorn (2014) in Es gibt einfach viel zu viel Texte

64 Cf. Eigenart und Potenzial des Weber-Paradigmas.

65 Mario Rainer Lepsius (1993a, p. 25-50) in Parteiensystem und Sozialstruktur. Zum Problem der Demokratisierung der deutschen Gesellschaft. See also: Hübinger (2008, p. 207-227) in Sozialmoralisches Milieu. Ein Grundbegriff der deutschen Geschichte; Lepsius (1993b, 95-1 18) in Das Modell der charismatischen Herrschaft und seine Anwendbarkeit auf den "Führerstaat" Adolf Hitlers.

66 Cf. Lepsius (2003, p. 32) in Eigenart und Potenzial des Weber-Paradigma. On the other hand, Wolfgang Schluchter prefers to speak of a "Weberian research program". Cf. Schluchter (2003, p. 45) in Handlung,Ordnung und Kultur. Grundzüge eines weberianischen Forschungsprogramms. 
structures, and personalities possessing cultural significance” (WEBER, [1919-1920] 2013a, p. 169, [1922] 2013c, p. 19).67

\section{Referências}

BAUMGARTEN, Eduard. Max Weber. Werk und Person. Tübingen: Mohr Siebeck, 1964.

BRUCH, Rüdiger vom; GRAF, Friedrich Wilhelm; HÜBINGER, Gangolf (ed.). [1889]. Kultur und Kulturwissenschaften um 1900. Krise der Moderne und Glaube an die Wissenschaft. Verlag: Stuttgart, 1997.

CHALCRAFT, David J.; HARRINGTON, Austin. The Protestant Ethic Debate. Max Weber's Replies to his Critics 1907-1910. Liverpool: Liverpool University Press, 2001.

HABERKORN, Tobias. Es gibt einfach viel zu viel Texte. Frankfurter Allgemeine Zeitung, n. 263, nov. 12, 2014.

HANKE, Edith. Rivoluzione e carisma. Concetti del cambiamento nel pensiero di Max Weber. Politica \& Società - Periodico di filosofia politica e studie sociali, v. 2, n. 1, p. 11-32, 2013.

HANKE, Edith. Max Weber und die historische Empirie. In: GRAF, Friedrich Wilhelm; HANKE, Edith; PICHT, Barbara (ed.). Geschichte intellektuell. Theoriegeschichtliche Perspektiven. Tübingen: Mohr Siebeck, 2015. p. 137-153.

HIBOU, Béatrice. De l'intérêt de lire La Domination de Max Weber aujourd'hui. Lectures. Les notes critiques, [s. l.], p. 2-21, 2014.

HIDAS, Zoltá. Entzauberte Geschichte. Max Weber und die Krise des Historismus. Frankfurt am Main: Suhrkamp Verlag, 2004.

HÜBINGER, Gangolf. Max Weber und die historischen Kulturwissenschaften. In: HAMMERSTEIN, Notker (ed.). Deutsche Geschichtswissenschaft um 1900. Stuttgart; Weimar: Verlag JB Metzler, 1988. p. 269-282.

HÜBINGER, Gangolf. Die "Rückkehr” der Kulturgeschichte, In: CORNELISSEN, Christoph (ed.). Geschichtswissenschaften. Eine Einführung, Frankfurt am Main: Suhrkamp Verlag, 2000. p. 162-177.

HÜBINGER, Gangolf. Universalgeschichtliche Probleme im Anschluß an Max Weber. Erwägen. Wissen. Ethik, v. 13, p. 97-99, 2002.

HÜBINGER, Gangolf. Kapitalismus, Religion und Herrschaft. Max Webers “universalgeschichtliche Probleme”. In: HÜBINGER, Gangolf. Gelehrte, Politik und Öffentlichkeit. Eine Intellektuellengeschichte. Göttingen: Vandenhoeck \& Ruprecht, 2006. p. 132-160.

67 Cf. Soziologische Grundbegriffe in MWG I/23 (WEBER, [1919-1920] 2013a); Economy and Society (WEBER, [1922] 2013). 
HÜBINGER, Gangolf. Sozialmoralisches Milieu. Ein Grundbegriff der deutschen Geschichte. In: SIGMUND, Steffen; ALBERT, Gert; BIENFAIT, Agathe; STACHURA, Mateusz (ed.). Soziale Konstellationen und historische Perspektive. Festschrift für M. Rainer Lepsius. Wiesbaden: VS Verlag, 2008. p. 207-227.

HÜBINGER, Gangolf. Die "Staatssoziologie" Max Webers. In: PEINE, Franz-Joseph; WOLFF, Heinrich Amadeus (ed.). Nachdenken über Eigentum. Festschrift für Alexander v. Brünneck zur Vollendung seines siebzigsten Lebensjahres. Baden, Nomos, 2011a. p. 443-452.

HÜBINGER, Gangolf. Max Webers Geschichtsdenken. Jahrbuch für Universitätsgeschichte, v. 12, p. 75-86, 2011 b.

HÜBINGER, Gangolf. Über die Aufgaben des Historikers. Berlin: Vergangenheitsverlag, 2012. KOCKA, Jürgen. Zwischen Elfenbeinturm und Praxisbezug. Max Weber und die "Objektivität" der Kulturwissenschaften. In: GNEUSS, Christiane; KOCKA, Jürgen (ed.). Max Weber. Ein Symposium. München: Deutscher Taschenbuch Verlag, 1988. p. 184-194.

KOSELLECK, Reinhart. Geschichte, Historie. In: BRUNNER, Otto; CONZE, Werner; KOSELLECK, Reinhart (ed.). Geschichtliche Grundbegriffe. Historisches Lexikon zur politischsozialen Sprache in Deutschland, vol. 2. Stuttgart; Weimar: Verlag JB Metzler, 1979. p. 593-595.

KROLL, Thomas. Die Max-Weber-Rezeption in der westdeutschen Historiographie. In: CORNELISSEN, Christoph (ed.). Geschichtswissenschaft im Geist der Demokratie. Wolfgang J. Mommsen und seine Generation. Berlin: Akademie Verlag, 2010. p. 189-205.

LEPSIUS, Mario Rainer. Zum Verhältnis von Geschichtswissenschaft und Soziologie. In: BAUMGARTNER, Hans Michael; SEMINAR, Jörn Rüsen. Geschichte und Theorie. Umrisse einer Historik. Frankfurt am Main: Suhrkamp Verlag, 1982. p. 118-138.

LEPSIUS, Mario Rainer. Interessen und Ideen. Die Zurechnungsproblematik bei Max Weber. In: LEPSIUS, Mario Rainer. Interessen, Ideen und Institutionen, Opladen: Westdeutscher Verlag, 1990. p. 31-43.

LEPSIUS, Mario Rainer. Parteiensystem und Sozialstruktur. Zum Problem der Demokratisierung der deutschen Gesellschaft. In: LEPSIUS, Mario Rainer. Demokratie in Deutschland. Soziologisch-historische Konstellationsanalysen. Ausgewählte Analysen. Göttingen: Vandenhoeck \& Ruprecht, 1993a. p. 25-50.

LEPSIUS, Mario Rainer. Das Modell der charismatischen Herrschaft und seine Anwendbarkeit auf den "Führerstaat" Adolf Hitlers, In: LEPSIUS, Mario Rainer. Demokratie in Deutschland. Soziologisch-historische Konstellationsanalysen. Ausgewählte Analysen, Göttingen: Vandenhoeck \& Ruprecht, 1993b. p. 95-118.

LEPSIUS, Mario Rainer. Eigenart und Potenzial des Weber-Paradigmas. In: ALBERT, Gert; BIENFAIT, Agathe; SIGMUND, Steffen; WENDT, Claus (ed.). Das Weber-Paradigma. Studien 
zur Weiterentwicklung von Webers Forschungsprogramm. Tübingen: Mohr Siebeck, 2003. p. 32-41.

MARX, Karl. Das Elend der Philosophie. In: Marx-Engels Werke. Band 4. Berlin: Dietz Verlag, 1972. p. 63-182.

MOMMSEN, Wolfgang J. Max Webers Begriff der Universalgeschichte. In: KOCKA, Jürgen (ed.). Max Weber, der Historiker. Göttingen: Vandenhoeck \& Ruprecht, 1986. p. 51-72.

MOMMSEN, Wolfgang J. Max Weber als Nationalökonom. Von der Theoretischen Nationalökonomie zur Kulturwissenschaft. Sociologia Internationalis. Internationale Zeitschrift für Soziologie, Kommunikations-und Kulturforschung, v. 42, p. 3-35, 2004.

OXELE, Otto Gerhard (ed.). Das Problem der Problemgeschichte. Göttingen: Wlallstein Verlag, 2011.

RADBRUCH, Gustav. Die Lehre von der adäquaten Verursachung. Berlin, Vergangenheitsverlag, 1902.

RICKERT, Heinrich. Die Grenzen der naturwissenschaftlichen Begriffsbildung. Eine logische Einleitung in die historischen Wissenschaften. Tübingen: Mohr Siebeck, 1896.

SCHLUCHTER, Wolfgang. Handlung, Ordnung und Kultur. Grundzüge eines weberianischen Forschungsprogramms. In: ALBERT, Gert; BIENFAIT, Agathe; SIGMUND, Steffen; WENDT, Claus (ed.). Das Weber-Paradigma. Studien zur Weiterentwicklung von Webers Forschungsprogramm. Tübingen: Mohr Siebeck, 2003. p. 42-74.

SCHLUCHTER, Wolfgang. Wie Ideen in der Geschichte wirken: Exemplarisches in der Studie über den asketischen Protestantismus. In: GRAF, Friedrich Wilhelm; SCHLUCHTER, Wolfgang (ed.). Asketischer Protestantismus und der “Geist” des modernen Kapitalismus. Max Weber und Ernst Troeltsch. Tübingen: Mohr Siebeck, 2005. p. 49-73.

SOMBART, Werner. Der Moderne Kapitalismus. vol. I. Leipzig: Duncker \& Humblot, 1902.

WEBER, Max. Wirtschaftsethik der Weltreligionen. Konfuzianismus und Taoismus. Schriften 1915-1920 (MWG I/19). [1915-1920]. Ed. by Helwig Schmidt-Glintzer in cooperation with Petra Kolonko. Tübingen: Mohr Siebeck, 1989.

WEBER, Max. Wissenschaft als Beruf. In: WEBER, Max. Wissenschaft als Beruf 1917/1919 - Politik als Beruf 1919 (MWG I/17). [1917-1919]. Ed. by Wolfgang J. Mommsen. Wolfgang Schluchter in cooperation with Birgitt Morgenbrod. Tübingen: Mohr Siebeck, 1992.

WEBER, Max. Wirtschaft und Gesellschaft. Nachlass. Teilband: Herrschaft (MWG I/22-4). Ed. by Edith Hanke in cooperation with Thomas Kroll. Tübingen: Mohr Siebeck, 2005.

WEBER, Max. Allgemeine (“theoretische”) Nationalökonomie. Vorlesungen 1894-1898 (MWG III/1). [1894-1898]. Ed. by Wolfgang J. Mommsen in cooperation with Cristof Judenau; Heino H. Nau; Klaus Scharfen and Marcus Tiefel. Tübingen: Mohr Siebeck, 2009a. 
WEBER, Max. Allgemeine Staatslehre und Politik (Staatssoziologie). Unvollendet. Mit-und Nachschriften 1920, MWG III/7. [1920]. Ed. by Gangolf Hübinger in cooperation with Andreas Terwey, Tübingen: Mohr Siebeck, 2009b.

WEBER, Max. Wirtschaft und Gesellschaft. Entstehungsgeschichte und Dokumente. MWG I/24. presented and ed. by Wolfgang Schluchter. Tübingen: Mohr Siebeck, 2009c.

WEBER, Max. Collected methodological writings (CMW). Ed. by Hans Henrik Bruun and Sam Whimster. London; New York: Macmillan, 2012.

WEBER, Max. Soziologische Grundbegriffe. In: WEBER, Max. Wirtschaft und Gesellschaft. Soziologie. Unvollendet 1919-1920 (MWG I/23). [1919-1920]. Ed. by Knut Borchardt; Edith Hanke; Wolfgang Schluchter. Tübingen: Mohr Siebeck, 2013a. p. 146-215.

WEBER, Max. Die Typen der Herrschaft. In: WEBER, Max. Wirtschaft und Gesellschaft. Soziologie. Unvollendet 1919-1920 (MWG I/23). [1919-1920]. Ed. by Knut Borchardt; Edith Hanke; Wolfgang Schluchter. Tübingen: Mohr Siebeck, 2013b. p. 455-508.

WEBER, Max. Economy and Society. [1922]. Ed. by Guenther Roth; Claus Wittich. 3rd ed. 2 vols. Berkeley: University of California Press, 2013c.

WEBER, Max. Briefe 1913-1914 (MWG II/8). [1913-1914]. Ed. by M. Rainer Lepsius; Wolfgang J. Mommsen in cooperation with Birgit Rudhard; Manfred Schön, Tübingen: Mohr Siebeck, 2003d.

WEBER, Max. Asketischer Protestantismus und Kapitalismus. Schriften und Reden 19041911 (MWG I/9). [1904-1911]. Ed. by Wolfgang Schluchter in cooperation with Ursula Bube. Tübingen: Mohr Siebeck, 2014.

WEBER, Max. Briefe 1903-1905 (MWG II/4). [1903-1905]. Ed. by Gangolf Hübinger, Mario Rainer Lepsius in cooperation with Thomas Gerhards und Sybille Oßwald-Bargende, Tübingen: Mohr Siebeck, 2015.

WEBER, Max. Zur Logik und Methodik der Sozialwissenschaften. Schriften [1900-1907] (MWG I/7) [1900-1907]. Ed. by Gerhard Wagner in cooperation with Claudius Härpfer; Tom Kaden; Kai Müller; Angelika Zahn. Tübingen: Mohr Siebeck, 2018a.

WEBER, Max. Die "Objektivität" sozialwissenschaftlicher und sozialpolitischer Erkenntnis. In: WEBER, Max. Zur Logik und Methodik der Sozialwissenschaften. Schriften 1900-1907 (MWG I/7) [1900-1907]. Ed. by Gerhard Wagner in cooperation with Claudius Härpfer; Tom Kaden; Kai Müller; Angelika Zahn. Tübingen: Mohr Siebeck, [1900-1907] 2018b. p. 135-234.

WEBER, Max. Kritische Studien auf dem Gebiet der kulturwissenschaftlichen Logik. In: WEBER, Max. Zur Logik und Methodik der Sozialwissenschaften. Schriften 1900-1907 (MWG I/7) [1900-1907]. Ed. by Gerhard Wagner in cooperation with Claudius Härpfer; Tom Kaden; Kai Müller; Angelika Zahn. Tübingen: Mohr Siebeck, 2018c. p. 380-571. 
WEBER, Max. Über einige Kategorien der verstehenden Soziologie. In: WEBER, Max. Verstehende Soziologie und Werturteilsfreiheit. Schriften und Reden 1908-1917 (MWG I/12). [1908-1917]. Ed. by Johannes Weiß in cooperation with Sabine Frommer. Tübingen: Mohr Siebeck, 2018d. p. 383-440.

WEBER, Max. Beitrag zur Werturteildiskussion im Ausschußdes Vereins für Sozialpolitik. In: WEBER, Max. Verstehende Soziologie und Werturteilsfreiheit. Schriften und Reden 1908-1917 (MWG I/12). [1908-1917]. Ed. by Johannes Weiß in cooperation with Sabine Frommer. Tübingen: Mohr Siebeck, 2018e. p. 329-382.

WEBER, Max. Der Sinn der "Wertfreiheit" der soziologischen und ökonomischen Wissenschaften. In: WEBER, Max. Verstehende Soziologie und Werturteilsfreiheit. Schriften und Reden 19081917 (MWG I/12). [1908-1917]. Ed. by Johannes Weiß in cooperation with Sabine Frommer. Tübingen: Mohr Siebeck, 2018f. p. 441-460.

Recebido: 01/06/2020 Aprovado: 07/08/2020 


\section{Max Weber e a investigação histórico-empírica}

\section{Resumo}

Max Weber é um sociólogo respeitado mundialmente; mas, existem outras maneiras de abordar e apreender sua obra, especialmente na ciência histórica. Ele foi visto como o último polyhistor de língua alemã, como o pai fundador dos estudos histórico-culturais e até mesmo como o precursor de uma historiografia orientada por problemas. Ao mesmo tempo, a história fornece a ele um reservatório praticamente inesgotável de dados empíricos. Weber demonstra que dados são cientificamente interessantes e como é possível utilizá-los para tratar questões científicas. A abordagem que adotarei neste ensaio seguirá os seguintes passos: primeiramente, identificarei as reflexões metodológicas de Weber sobre como lidar com a realidade histórico-empírica. Em segundo lugar, mostrarei como Weber incorpora a história com foco especial em sua sociologia da dominação - uma seção central de Economia e Sociedade. Finalmente, explorarei brevemente as possibilidades que se abrem às ciências históricas atuais com a adoção das principais teses de Weber.

Palavras-chave: Max Weber. Conhecimento histórico-empírico. Ciência da realidade. Sociologia da dominação. 